\title{
ICSID CASES IN 2020, AFFECTED OR NOT BY COVID 19
}

\author{
Mihai BERINDE, Dana Maria PETRICA, Liana-Eugenia MESTER \\ Faculty of Economic Sciences, University of Oradea, Oradea, Romania \\ mihai.berinde@yahoo.com \\ danamester@yahoo.com \\ Imester@uoradea.ro
}

\begin{abstract}
The present paper intends to present the evolution registered in the ICSID - International Centre for Settlement of Investment Disputes - cases during FY2020, comparing with the historical evolution, in order to identify the possible effect of COVID 19 on the dynamics of registering and administrating cases and also in the hearings, if any. Many economic sectors had been deeply affected by the pandemic, and they have shown a real capability to adapt their way of acting and doing things. International arbitration made no difference, and it showed a real adaptive capacity, allowing the existing cases to follow their path and also registering new cases without delays. In 16 April 2020 the leading organisation of arbitration (the CRCICA, DIS, ICC, ICDR/AAA, ICSID, KCAB, LCIA, MCA, HKIAC, SCC, SIAC, VIAC and the International Federation of Commercial Arbitration Institutions) released a common statement on COVID 19: "Collaboration is particularly important as each of our institutions looks to ensure that we make the best use of digital technologies for working remotely." The first element to be notice in the 2020 ICSID Statistics is the fact that the number of the cases registered during 2020 had touched a new record, 58 new cases. The previous record was of 56 , and was registered in 2018, meanwhile in 2019 there were registered 39 new cases. One big difference occurred in the way of holding the hearings, in the last 9 months of the year 2020 , all the hearings were held remotely, $78 \%$ by video and $22 \%$ by phone. ICSID had developed and used their one video conferencing platform. In terms of industry, States parties involved, proceedings outcomes, nationality of arbitrators appointed there were some evolutions but with no significant changes.
\end{abstract}

Keywords: ICSID, damages, foreign direct investment, international disputes

JEL classification: F51; F37; K22

\section{Introduction}

The International Centre for Settlement of Investment Disputes Convention was established in October 1966 by the Convention on the Settlement of Investment Disputes between States and Nationals of Other States (the ICSID Convention).

Arbitration under International Investment Agreements. A Guide to the Key Issues (Yannaca-Small K., 2010) provides, in a logical and accessible manner, the procedural aspects of arbitration and describes the conflicts and challenges that arbitrators face from a practical perspective. The second edition of this guide (Yannaca-Small K., 2018) presents, from an intelligent perspective, a complete update of all procedural issues. 
Disputes are often the result of the use of incentives, which is why their use is rarely a good policy, especially for countries without adequate education and infrastructure (Kenneth Th., 2010). Given that disputes and cooperation between states are the result of economic problems, the legal foundations of the international economy are examined and political tensions and generated results are explored (Lowenfeld, A.F., 2002).

Findings and perspectives on how the benefits of FDI can be improved, but also the limitation or elimination of potential damages as a result of disputes between states or investor and state, are examined in extensive analyzes (Moran Th. M., 2011).

The present study is a continuation of previous studies published by the same authors.

Since 1972, when the first case of arbitration was registered at ICSID, the majority disputes between foreign investors and States were arbitrated by ICSID. Year by year the number of cases had increased significantly.

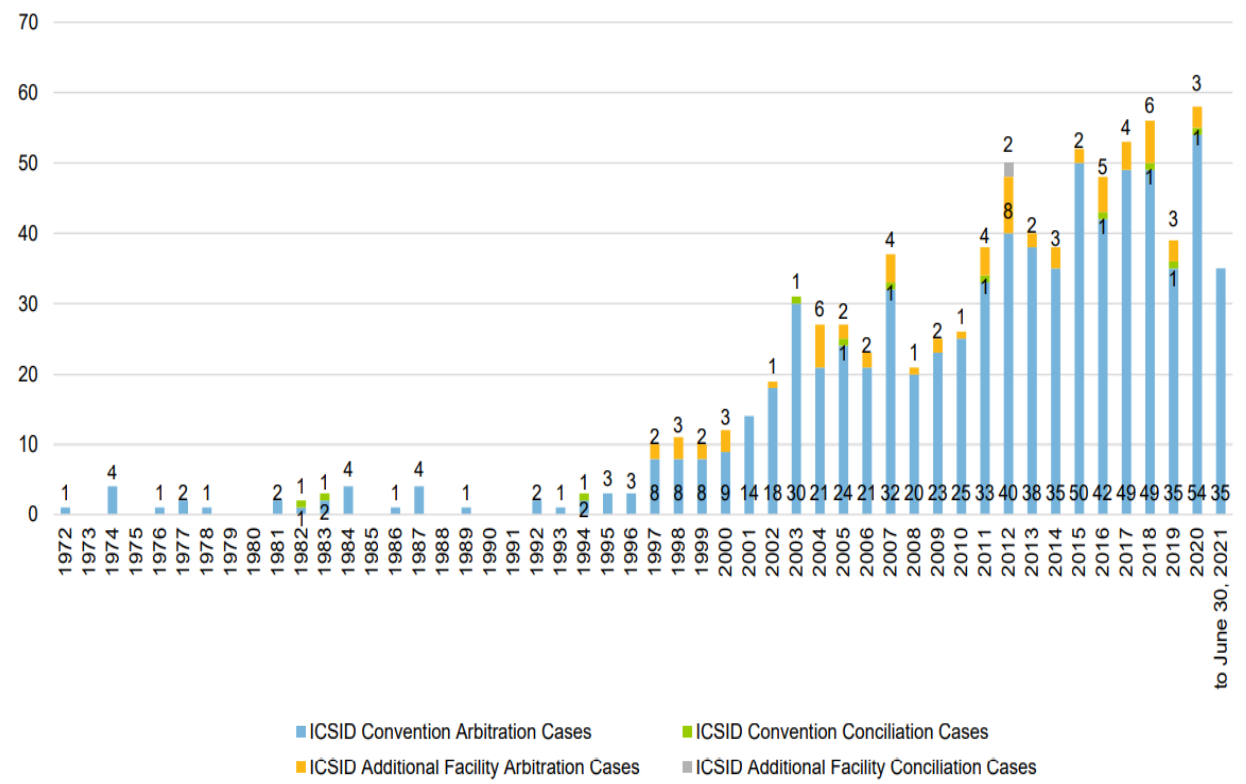

Figure 1: Number of ICSID Cases Registered, by Calendar Year Source: https://icsid.worldbank.org, date: 01.11 .2021

ICSID cases can be split between: ICSID Convention Arbitration Cases, ICSID Convention Conciliation Cases, ICSID Additional Facility Arbitration Cases or ICSID Additional Facility Conciliation Cases. Over 90\% of the cases are ICSID Convention Arbitration Cases.

The resolution for a case needs a period of several years, that is the reason why the Secretariat of ICSID is administrating a high number of cases each year. 


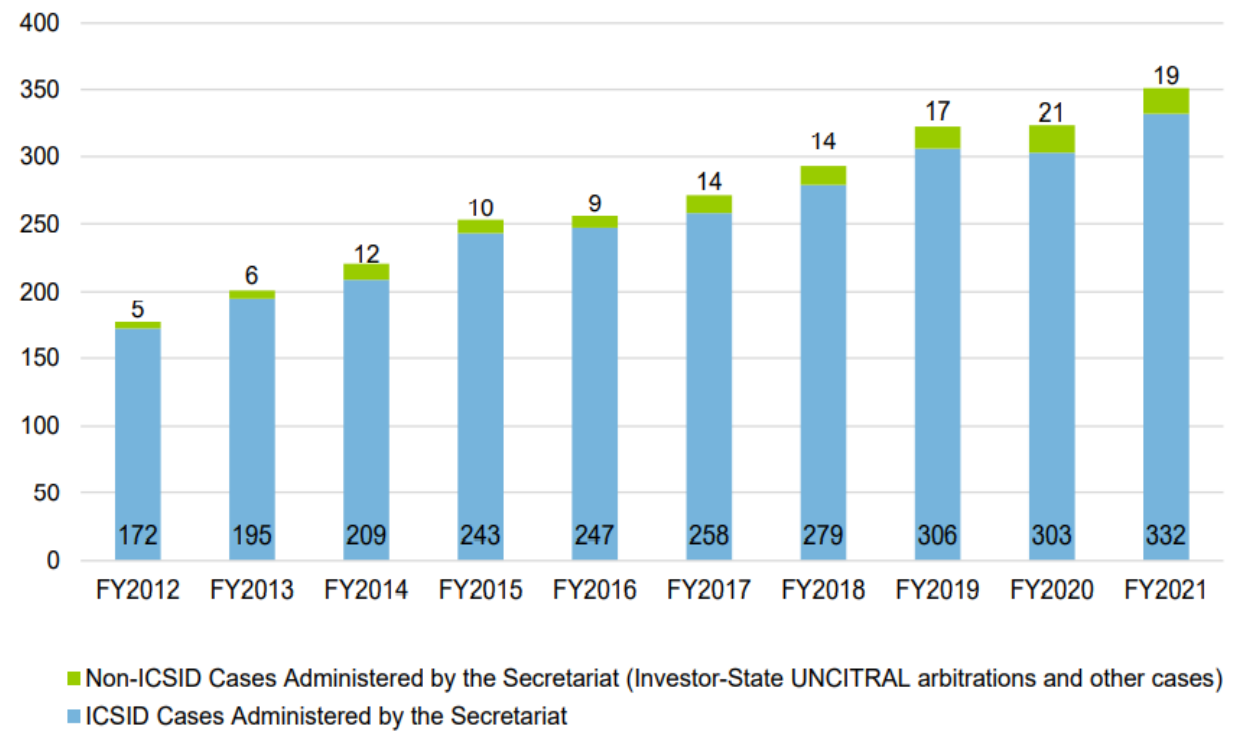

Figure 2: Total Cases Administered by the ICSID Secretariat, under ICSID and Non-ICSID Rules

Source: https://icsid.worldbank.org, date: 01.11.2021

\section{ICSID Cases in FY 2020 2.1. Concluded cases}

In 2020, 303 ICSID cases were administered (40 new ICSID cases) - the second highest number of cases ever administered at ICSID in a single fiscal year (FY). Since 1972 when the first ICSID case was registered, have been administered 768 cases under the ICSID Convention and Additional Facility Rules. In 2020, 37 cases were arbitrations instituted under the ICSID Convention and 3 cases were arbitrations invoking the Additional Facility Rules. (ICSID Annual Report, 2020).

As we can see from the above figures the number of registered cases in 2020 was higher than any of the number of cases registered in previous years, and in terms of cases administrated by the ICSID Secretariat the number of the cases did not increase in the same proportion, that give as a first clue about the numbers of cases that were concluded or terminated during FY2020. BY the end of FY 5168 cases had been concluded. In FY 2020 a number of 68 cases were concluded and in 2019 a number of 59 cases. The economic sectors involved in ICSID proceedings are also diverse. As in previous years, in 2020 most cases come from the extractive and energy industries: $30 \%$ of cases are from the oil, gas and mining industry, $20 \%$ are cases related to energy sources (electricity and other energy sources), $17 \%$ are cases involving construction and the other cases are from information and communication, finances, transportation, agriculture, fishing and forestry, services and trade. Most disputes were decided by the courts $(74 \%)$; the others disputes (26\%) have been resolved or are being resolved, their discussion being interrupted. 


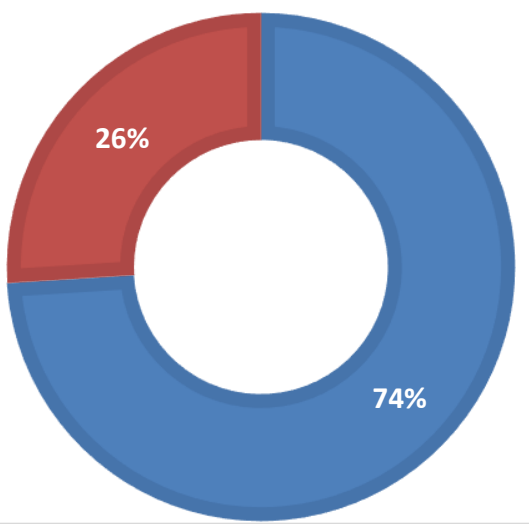

-Dispute decided by Tribunal

-Dispute settled or proceeding otherwise discontinued

Figure 3: Arbitration Proceedings under the ICSID Convention and Additional Facility Rules - Outcomes 2020

Source: https://icsid.worldbank.org, date: 01.11 .2021

From the disputes decided by the Tribunal the main majority were keeping the claims in part or in total:

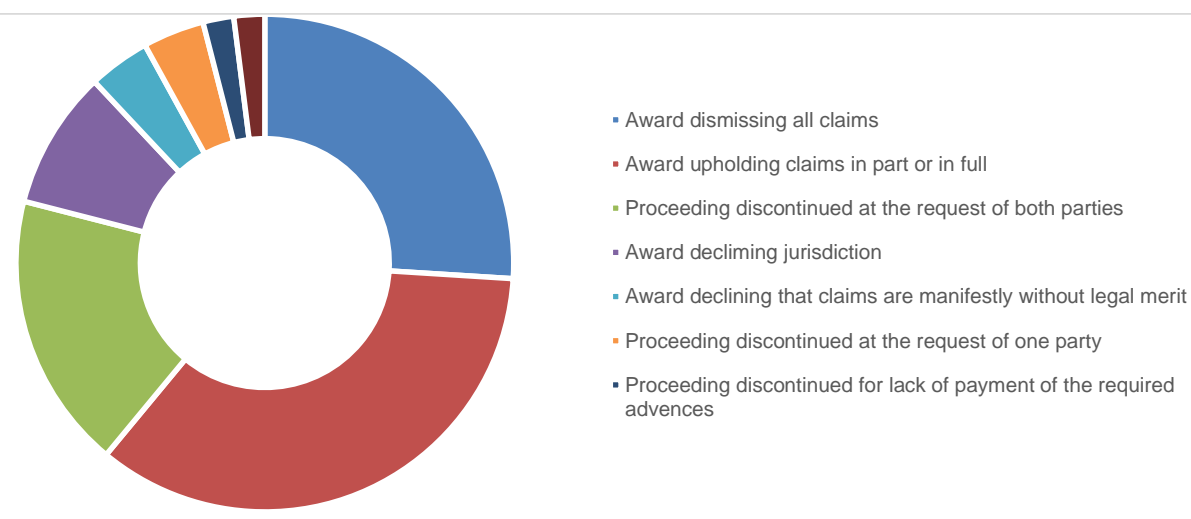

Figure 4: Arbitration Proceedings under the ICSID Convention and Additional Facility Rules - Tribunal Rulings, Settlement \& Discontinuances

Source: https://icsid.worldbank.org, date: 01.11.2021

\subsection{Jurisdiction and regions and economic sectors in 2020 vs. 2019}

In 2019, 306 ICSID cases were administered (52 new ICSID cases). Since 1972 when the first ICSID case was registered, have been administered 728 cases under the ICSID Convention and Additional Facility Rules. In 2019, 47 cases were arbitrations instituted under the ICSID Convention and 4 cases were arbitrations 
invoking the Additional Facility Rules, also one conciliation was registered under the ICSID Convention. (ICSID Annual Report, 2019).

In terms of jurisdiction, regions and economic sectors, in the figures below we can see the evolution from 2019 to 2020.

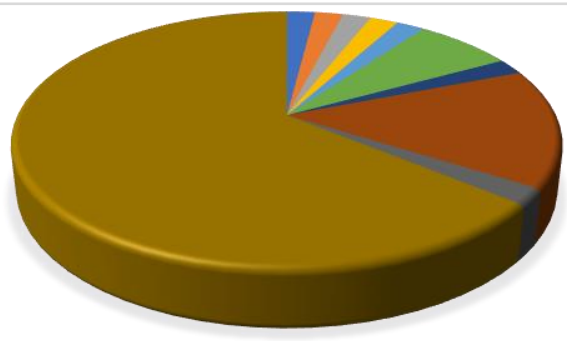

aUS - Columbia Trade Promotio Agreement $2 \%$

aCanada-Columbia Free Trade Agreement 2\%

Aentral America - Panama Free Trade Agreement 2\%

aPeru-Singapore Free Trade Agreement $2 \%$

aUS-Morocco Free Trade Agreement 2\%

aEnergy Charter Treaty $7 \%$

aNorth America Free Trade Agreement 2\%

alnvestment Contract between the Investor and the Host-State 15\%

aDominican Republic-United States-Central America Free Trade Agreement 2\%

Bilateral Investment Treaty 64\%

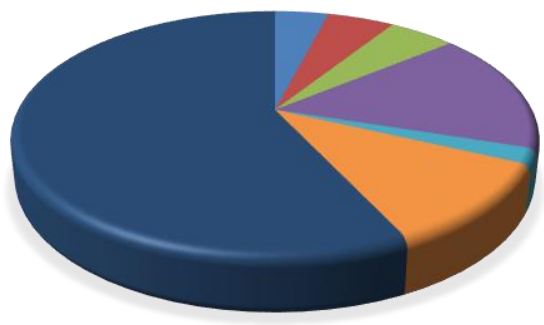

QUS - Columbia Trade Promotio Agreement $2 \%$

aUS - Peru Trade Promotion Agreement 5\%

alnvestment Law of the Host-State $5 \%$

Energy Charter Treaty 16\%

ANorth America Free Trade Agreement 2\%

A Investment Contract between the Investor and the Host-State 11\%

ailateral Investment Treaty 57\%

2020

Figure 5: Basis for deciding jurisdiction in 2019 vs 2020

Source: https://icsid.worldbank.org, date: 01.11.2021

We can see from the figure 5 that most of the cases registered at ICSID were under the jurisdiction of BITs - Bilateral Investment Treaties, in 2019 and also 2020 the percentage of the cases under this section was more than $50 \%$. There is a little decrease in the percentage, and we can see the increase in the jurisdiction of 
Energy Charter Treaty, but this has also been seen in some of the previous years, so without a direct link to the pandemic situation.

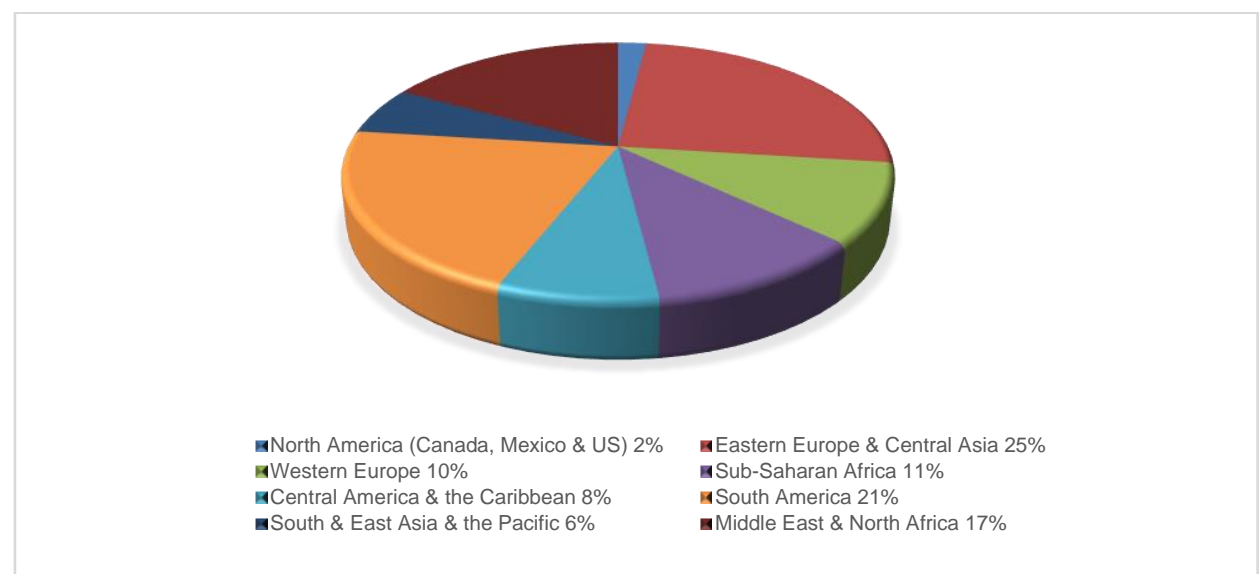

\section{9}

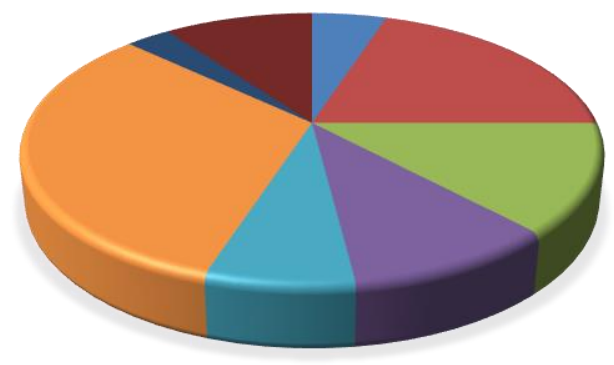

aNorth America (Canada, Mexico \& US) 5\% QWestern Europe 13\%

aCentral America \& the Caribbean $7 \%$ atern Europe \& Central Asia 20\%

aSouth \& East Asia \& the Pacific 3\% Sub-Saharan Africa 10\% ASouth America 32\% Middle East \& North Africa 10\%

\section{0}

Figure 6: Regions in 2019 vs 2020

Source: https://icsid.worldbank.org,date: 01.11 .2021

The figure 6 indicates that Europe had in 2019 35\% of the cases and in 2020,32\%, mainly with a stability from year to year. The change can be seen between America and Africa, Africa dropping with 8 percentage's points and America increasing with $13 \%$, in total America being in 2020 on the first place with a total of $44 \%$ from the cases number, in 2019 Europe had registered the higher percentage from the number of cases, 35\%, America having 31\%. America and Europe were switching between them the first 2 places in the previous years as well. 
Information \& Communication 6\% aOil, Gas \& Mining 21\%

ATransportation 6\%

aConstruction $15 \%$
Agriculture, Fishing \& Forestry $4 \%$

aFinance $11.5 \%$

OOther Industry $11.5 \%$

Water, Sanitation \& Flood Protection 4\%

2019

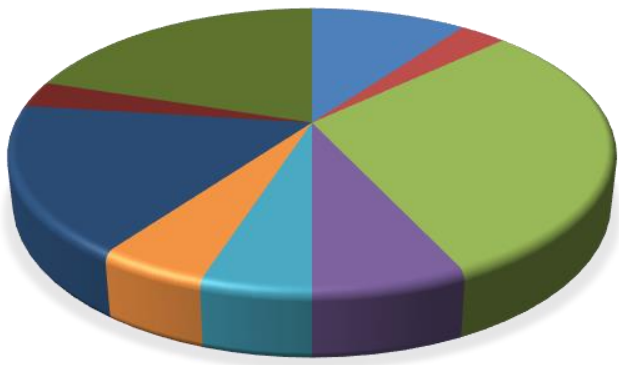

AInformation \& Communication 10\% QOil, Gas \& Mining 30\%

QTransportation $5 \%$

aConstruction $17 \%$
Agriculture, Fishing \& Forestry 3\% AFinance $7 \%$

QOther Industry 5\%

QServices and Trade 3\%

\section{0}

Figure 7: Economic sectors in 2019 vs 2020

Source: https://icsid.worldbank.org,date: 01.11 .2021

In terms of economic sectors the first three places are being covered by Oil, Gas \& Mining, Electric Power \& Other Energy and Construction. In 2019, these three industries were covering $57 \%$ of all the cases and in 2020 they were covering $67 \%$

\subsection{Hearing, proceedings and other differences in 2020 compared to 2019}

ICSID sessions and hearings had moved their activity in online, over $70 \%$ being held remotely, in the last 9 months of the year 2020, all the hearings were held remotely, $78 \%$ by video and $22 \%$ by phone.

In 16 April 2020 the leading organisation of arbitration (the CRCICA, DIS, ICC, ICDR/AAA, ICSID, KCAB, LCIA, MCA, HKIAC, SCC, SIAC, VIAC and the International Federation of Commercial Arbitration Institutions) released a common statement on COVID 19: "Collaboration is particularly important as each of our institutions looks to ensure that we make the best use of digital technologies for working remotely." 
Due to high investments in IT structure that ICSID had made during the years they were able to switch from IN PERSON scenario to HYBRID and then to VIRTUAL scenario with a speed that ensure all the cases respected their timeframe.

In IN PERSON scenario all the participants are in the same room on one of the 138th offices of World Bank or in the facilities of other arbitration institutions with which ICSID had signed agreements.

In HYBRID scenario the Tribunal is meeting in one location, the respondent team in other location and the claimant team in a third one, in the locations of World Bank or other arbitration institutions with which ICSID had signed agreements. Hybrid models were expected to be increasingly favored.

The third scenario, the VIRTUAL one, was the one most used during FY2020. This allows hundreds of participants to connect individually from their locations and each of them can share audio and video, documents, power point presentation, or any other type of files that they may need.

Court reporters and interpreters can also provide transcription and interpretation via dedicated text feeds and audio channels in the online conference and all the participants cand chat between them or with the entire group.

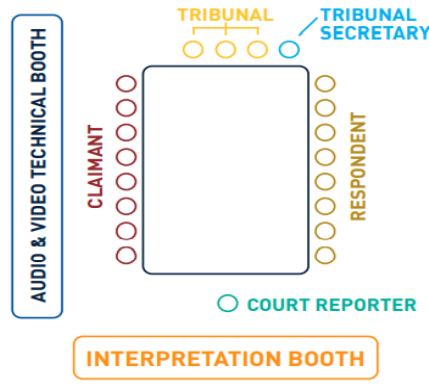

a

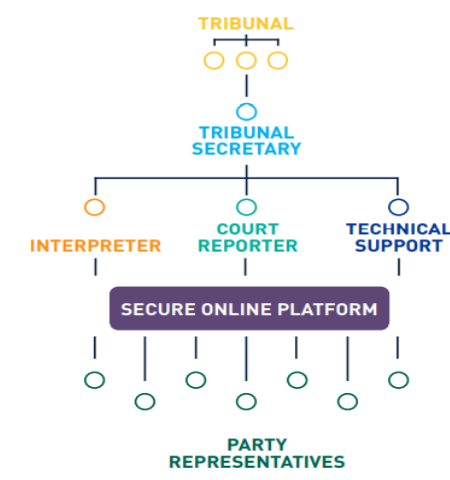

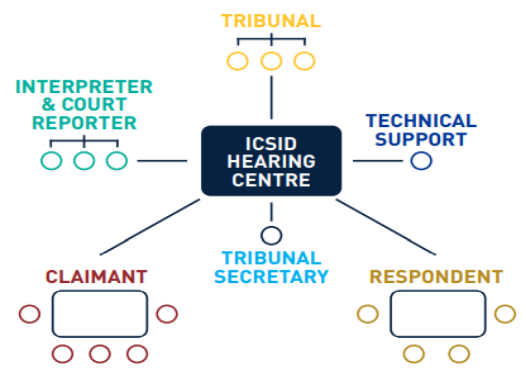

b

C

Figure 8: Scenarios

a: IN PERSON scenario b: HYBRID scenario c: VIRTUAL scenario

Source: https://icsid.worldbank.org,date: 01.11.2021 


\section{In conclusion}

TOM XXX, $2^{\text {nd }}$ Issue, December 2021

COVID-19 caused an unprecedented situation, generating a health crisis economic crisis and social crisis.

With all the problems that the pandemic brought, ICSID was following the path they had in the previous years, being able to switch to online with a speed they could not imagine before. It showed a very high capacity to adapt to all the new conditions and registering an increase in number of cases and even an increase in the number of state members, Dijibouti signed the ICSID Convention during 2020, becoming the $155^{\text {th }}$ member.

In terms of industry, States parties involved, proceedings outcomes, nationality of arbitrators appointed there were some evolutions but with no significant changes. An important increase of percentage of women appointed as arbitrators was also registered as compared whit the historical data, from $12 \%$ to $23 \%$.

Beside the way of holding sessions and hearings nothing looks like being affected by the COVID 19 pandemic.

\section{References:}

1. Berinde Mihai, Petrica Dana, Mester Liana, ICSID Cases in which damages were awarded based on market approach, Annals of University of Oradea, Economic Science, TOM XXVII 2018, Issue no 1 http://anale.steconomiceuoradea.ro/volume/ 2018/AUOES-1-2018.pdf.

2. Yannaca-Small, K. (2010), Arbitration under International Investment Agreements. A Guide to the Key Issues, New York: Oxford University Press.

3. Yannaca-Small, K. (2018), Arbitration under International Investment Agreements. A Guide to the Key Issues, Second Edition, New York: Oxford University Press.

4. Kenneth, Th. (2011), Investment Incentives and the Global Competition for Capital

(International Political Economy Series), Kindle Edition, Palgrave Macmillan, London.

5. Lowenfeld, A.F. (2002), International Economic Law, Oxford: Oxford University.

6. Moran, Th.M. (2011), Foreign Direct Investment and Development: Launching a Second Generation of Policy Research, Avoiding the Mistakes of the First, ReEvaluation developed and Developing Country, Washington, DC: Peterson Institute of International Economics.

7. Petrica, Dana (2017), The International Center for Settlement of Investment Disputes - Establishment, Role and Impact on Foreign Direct Investment, 23 November 2017 Emerging Markets Economics and Business. Contributions of Young Researchers. Proceedings of the Conference of Doctoral Students in Economic Sciences No. 5, University of Oradea Publishing, Oradea.

8. Ripinsky, S. and Kevin, W. (2008), Damages in International Investment Law, London: British Institute of International and Comparative Law.

9. ICSID Annual Report (2020), https://icsid.worldbank.org/sites/default/files/ publications/annual-report/en/ICSID AR20 CRA Web.pdf

10. ICSID Annual Report (2021), https://icsid.worldbank.org/sites/default/files/ publications/annual-report/en/ICSID AR21 CRA Web.pdf 